\title{
University IT infrastructure in the context of evolutionary transformations of the digital economy.
} УНИВЕРСИТЕТСКАЯ ИТ-ИНФРАСТРУКТУРА В КОНТЕКСТЕ ЭВОЛЮЦИОННЫХ ТРАНСФОРМАЦИЙ ЦИФРОВОЙ ЭКОНОМИКИ

\section{Infraestructura IT universitaria en el contexto de transformaciones evolucionarias de la economía digital.}

Kantemir V. Kaziev ${ }^{3}$, Anna A. Sherstobitova ${ }^{4}$, Bella V. Kazieva ${ }^{5}$

Abstract Education faces a new barrier - digital, which needs to be taken that to continue its evolutionary path of qualitative changes in the system and the entire educational environment. Universities solve problems of IT infrastructure renewal, educational technologies, integration of all components of infrastructure. For a knowledge-based society, motivation of students and employees of companies, employees of organizations to professional self-development is important. There is a need to build the evolutionary capacity of universities, teachers and students. Self-development of the future specialist is the base, the way of its self-regulation in the future professional community, the possibility to reveal the personal and creative potential, both in team and autonomous work. The information and educational infrastructure of the university forms competences, personal qualities of the student. It's necessary to carry out a systematic analysis of the goals, opportunities, ways of updating the information and educational environment as an innovative environment, combining resources, tools, methodologies of solving problems, in particular, and the management of the educational process. The trained, creative, creative and competent experts who will be able to realize the personal adaptive strategy of creative activity are needed. The article contains a systematic analysis, describes system-synergistic goals and approaches for the development of university infrastructure, strategic and tactical goals of universities, one of the main participants of digital transformations of the modern economy. Most attention is paid to scientific-methodological, information-logical support of the training process, situational modeling and decision-making.

Key words: information-logical, educational, university, infrastructure, self-development, motivation.

Аннотация

Образование сталкивается с новым барьером - цифровым, который необходимо принять, чтобы продолжить свой эволюционный путь качественных изменений в системе и всей образовательной среде. Университеты решают задачи обновления ИТ-инфраструктуры, образовательных технологий, интеграции всех компонентов инфраструктуры. Для общества, основанного на знаниях, важна мотивация студентов и сотрудников компаний, сотрудников организаций к профессиональному саморазвитию. Необходимо наращивать

\footnotetext{
${ }^{3}$ Deputy Head of the Department Russian Pension Fund in the Kabardino-Balkarian Republic Nalchik, Russia.

${ }^{4}$ Candidate of Economic Sciences, Associate Professor, Associate Professor of the Department of Finance and Credit Tolyatti State University Tolyatti, Russia.

${ }^{5}$ Candidate of Economic Sciences, Associate Professor, Associate Professor of the Department of Accounting Kabardino-Balkarian State University Nalchik, Russia.
} 
эволюционный потенциал университетов, преподавателей и студентов. Саморазвитие будущего специалиста - это основа, способ его саморегуляции в будущем профессиональном сообществе, возможность раскрыть личностный и творческий потенциал как в командной, так и в автономной работе. Информационно-образовательная инфраструктура вуза формирует компетенции, личностные качества студента. Необходимо проводить системный анализ целей, возможностей, путей обновления информационно-образовательной среды как инновационной среды, объединяющей ресурсы, средства, методики решения проблем, в частности, и управления образовательным процессом. Нужны подготовленные, творческие, креативные и компетентные специалисты, которые смогут реализовать свою личностную адаптивную стратегию творческой деятельности. В статье проводится системный анализ, описываются системно-синергетические цели и подходы развития университетской инфраструктуры, стратегические и тактические цели вузов, являющихся одним из основных участников цифровых преобразований современной экономики. Наибольшее внимание уделяется научно-методическому, информационно-логическому обеспечению учебного процесса, ситуационному моделированию и принятию решений.

Ключевые слова: информационно-логический, образовательный, университет, инфраструктура, саморазвитие, мотивация.

Resumen La educación enfrenta una nueva barrera: la digital, que debe tomarse para continuar su camino evolutivo de cambios cualitativos en el sistema y en todo el entorno educativo. Las universidades resuelven problemas de renovación de infraestructura de TI, tecnologías educativas, integración de todos los componentes de la infraestructura. Para una sociedad basada en el conocimiento, la motivación de los estudiantes y empleados de las empresas, los empleados de las organizaciones para el autodesarrollo profesional son importantes. Es necesario desarrollar la capacidad evolutiva de universidades, docentes y estudiantes. El autodesarrollo del futuro especialista es la base, la forma de su autorregulación en la futura comunidad profesional, la posibilidad de revelar el potencial personal y creativo, tanto en equipo como en trabajo autónomo. La infraestructura educativa y de información de la universidad forma competencias, cualidades personales del alumno. Es necesario llevar a cabo un análisis sistemático de las metas, oportunidades, formas de actualizar la información y el entorno educativo como un entorno innovador, combinando recursos, herramientas, metodologías para resolver problemas, en particular, y la gestión del proceso educativo. Se necesitan expertos capacitados, creativos, creativos y competentes que puedan realizar la estrategia personal adaptativa de la actividad creativa. El artículo contiene un análisis sistemático, describe objetivos y enfoques sinérgicos del sistema para el desarrollo de infraestructura universitaria, objetivos estratégicos y tácticos de las universidades, uno de los principales participantes de las transformaciones digitales de la economía moderna. Se presta la mayor atención al apoyo científico-metodológico, lógico-informativo del proceso de capacitación, modelado situacional y toma de decisiones.

Palabras clave: lógica de la información, educación, universidad, infraestructura, autodesarrollo, motivación.

\section{Introduction}

Society needs not only competent, but systemically and creative thinking specialists with university education. Especially they are lacking in the sphere of IT-directions. Universities are intensive in re-engineering infrastructure, modernizing educational technologies and adapting methodology, management and control to digital transformations. Educational and scientific resources, IT-support are integrated, the pace of integration of scientific and applied problems is increasing taking into account the wishes of employers (customers), region (consumers). There is a development in the broad sense of interdisciplinary ties, educational environment of universities.

Universities should introduce new standards and change the paradigm of vocational training. Together with fundamentality, compliance with GEF requirements, it's necessary to develop personal qualities of the student, his motivation for self-development all life. Researchers (e.g. Kalimullina, Islamova, 2016; Klug. et al, 2013; Efanova et 
improving the quality of training by SMART-universities.

Though often categories "infrastructure", "infrastructure environment of higher education institution" is associated with programs, technological procedures and innovations, we will understand them more widely - as the paradigm, technologies, methodologies, tools, resources and potential providing digital and intellectual development of scientific and educational process at the university.

\section{Theoretical bases}

Continuous self-study, self-development of the specialist - a way of self-regulation of creative activity by profession in the professional community. Self-development is defined as human activity in revealing the capabilities of a specialist, their personal potential, taking into account both the true and perceived values of IT infrastructure, the Internet (Kaziev, 2012).

The information and educational environment is the educational infrastructure, the environment both of the educational process itself (professors, tools, etc.) and of students, who form competencies, personal qualities for the development of society. From the point of view of system analysis, this set of educational situations, which evolutionally supports the model of vocational self-development of the future professional.

Such an environment integrates educational and communication resources and tools, including technology for managing the development of the creative personality. In the university - creative component - the most important: society awaits not just competent specialists, but creative, able to meet the growing intellectual needs of society.

Systematic analysis and synthesis of information and educational university environment, its educational potential, with necessity takes into account resources of environment:

1) educational (digital, intellectual and resource support);

2) network (automated and intelligent systems of training, control);

3) control (modules, courses, organizational, etc.);

4) self-organization (self-training, self-study, self-development and others).

It's important to take into account opportunities (management, training, technology, etc.) that cannot be achieved adequately to the goals of education in traditional education: development of intelligent algorithms, inventive solutions and tasks, etc.

The objectives of our synthesis analysis include:

1) methods of activation of creative abilities, in particular, situational testing (research, training);

2) situational (imitating) modeling;

3) decision-making methods (brainstorming, Delphi, etc.);

4) analytical methods (web, cognitive, etc.);

5) expert-heuristic procedures, etc.

Methods are necessary to achieve system-synergistic goals - independence, self-study, self-development of competences sufficient for adaptive orientation in the information and educational environment, development of independent personal educational strategy. This is necessary, for example, for the professional training of public servants (Vasilyev, Pulyayeva \& Yudina, 2018), as well as the development of mass and media communications (Gulevich, 2019).

Tactical, methodical, didactic goals are also considered:

1) adaptive testing (monitoring, certification, training);

2) harmonious "introduction" into an unfamiliar digital environment;

3) formation of self-esteem of students;

4) adaptive management of the process of training, self-study (diagnostics, adjustment, stimulation); 
Our goals are aimed at dynamic changes of competences and training, retraining of specialists who can:

1) quickly adapt and quickly;

2) critically assess problems and ways of effectively solving them digitally;

3) update digital solutions;

4) work in the team on various digital directions and levels.

\section{Methodology}

Mobility, on-the-fly solution, using only available learning resources, remote, distributed and cloud access to them, situational and continuous updating of IT-environment - necessary attributes of digital stage of university development (Nazarov, 2018).

Methods of pedagogical, psychological, system-analytical, mathematical, infological, etc., are used. GEF and programs are supported, including innovative and author programs (for example, Modeling in the Digital Economy and Business). Infrastructure activation methods and tools are also important, for the university the key ones are:

1) servers (file, mail, access to WWW and applications, remote learning, multimedia support class, etc.);

2) network and route facilities, scientific and educational laboratories;

3) open (Open Resource) solutions ("e-Learning server," e-Learning office, "Moodle," 1C, "Consultant Plus," Cloud Computing, "etc.).

\section{Results and discussion}

The system analysis provides the following relevant, priority solutions:

1) system-synergistic understanding of the category "information and educational environment (university)";

2) classification (by importance and resource availability) of tasks of training of competent specialists of the digital economy;

3) scientific-methodical, didactic, information-logical and mathematical support of the university infrastructure.

Let's look at the results for the last item in more detail.

First, a set of situational test assignments has been developed to support training in situational modeling of university students. For example, for the forecast of consequences of the technogenic actions which are carried out by the person (especially, negative). Mistakes should not be made in them, as they can lead to harmful consequences ("points of no return"). Due to the limited information capabilities of the person, errors are possible. Therefore, it is important to train students in situational modeling and forecasting of various situations, to make decisions related to organization of work, assessment of information, selection of the best option. To train the development of the situation and constructive actions to achieve the goals. The more efficient the solution is, the more likely the goal is to be achieved, the lower the cost. This determines the usefulness of the solution.

Situational modeling - simulation of decision-making in conditions of limited resources and high reliability (low risk of crisis). In situational analysis it is important to teach the selection of criteria, procedures for assessing the achievement of the goal (Kaziev, 2011). Examples of situation test jobs are given below.

Example. From the diagram of the sex and age structure of the population of the region (in thousand people): 


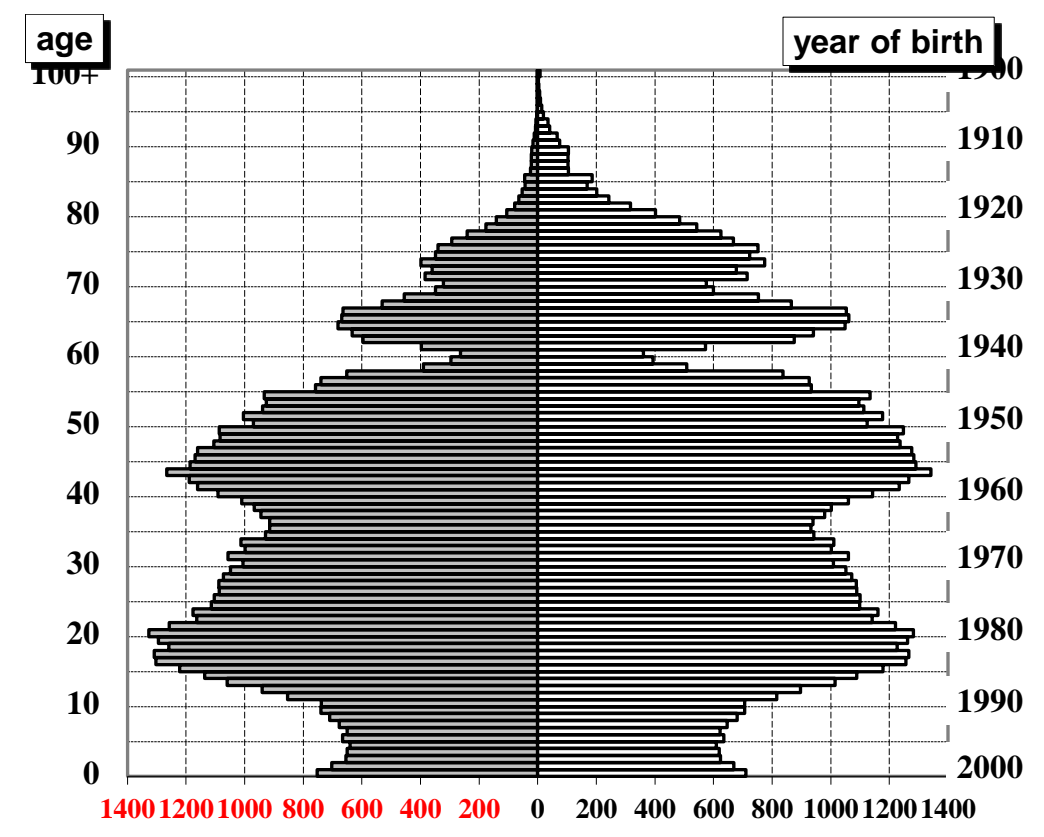

it follows that in 2000 :

1) the pension system had the highest "burden" on the budget;

2) receipt of income taxes into the budget was minimal;

3) birth rate has fallen compared to the last 5 years;

4) were fewer first-graders than in 1999.

Example. According to the diagram below,

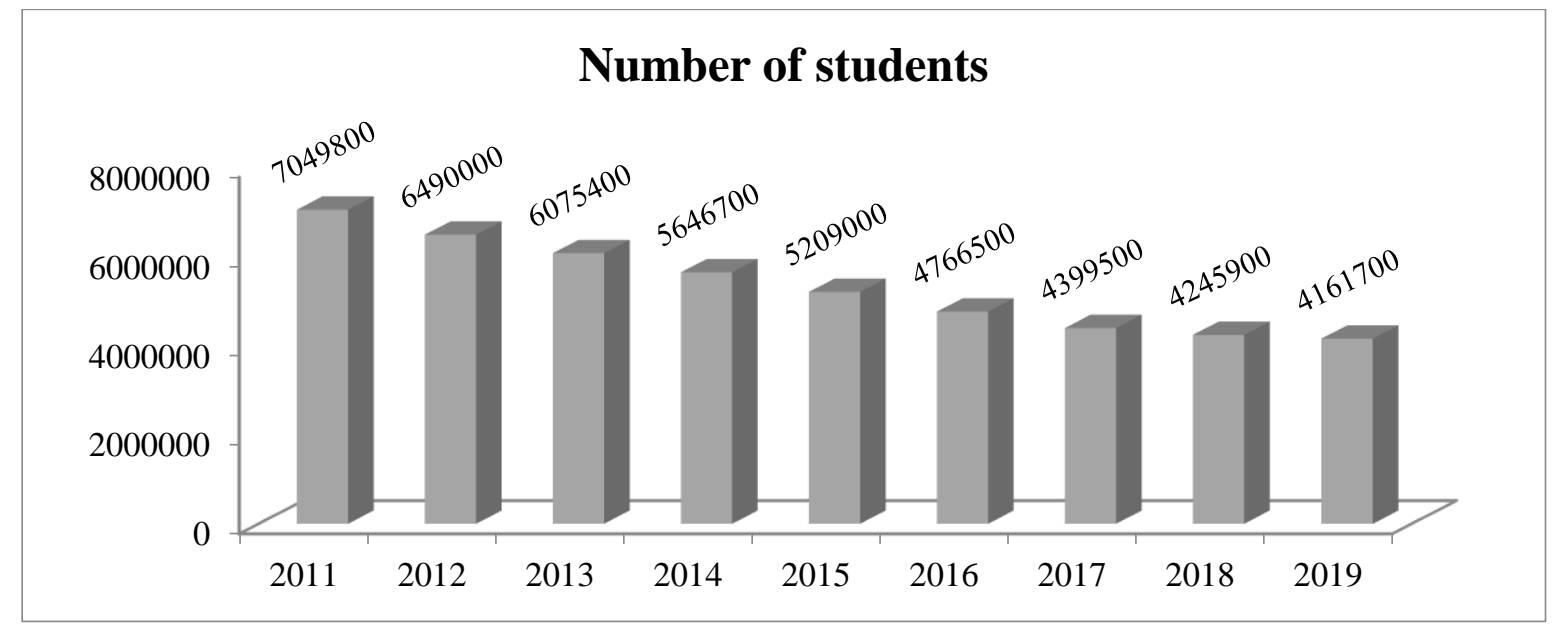

to define what of the functions $y=a x+b, y=a x^{b}, y=a e^{x}, y=(a x+b) /(c x+d)$ is the best model? Take residual dispersion as a measure of model adequacy.

Secondly, a set of models, tasks for situational decision-making and modeling have been developed. Let's give examples. 
Example. The work follows the SaaS model, the customer may not buy software, but pay for the service. The application can be adapted for remote mode, data can be placed in the cloud (on the service provider server). Multiple clients can use the same client application. Payment can be charged as a subscription fee or by volume of transactions. Specify at what expense and how time, money can be saved. What are the main advantages of the model? Does the model have flaws, and which ones? What type of contract is it best to regulate the relationship between the provider and the consumer of services under this model? How should you implement the business functions to the consumer, vendor? Do web analytics on cloud computing online.

Example. The company wants to install CCTV. Employees worry that the employer suspects them of bad faith. Some are concerned there will be an "invasion" of privacy. At a minimum, it will become less comfortable to work. What is the legal basis for installing video surveillance systems? How should management justify this procedure? How should it be implemented? Could it be considered a violation of an employee 's constitutional rights? What are the benefits and harms of deploying the system to the office? Can I install hidden cameras, under what conditions?

Example. Describe the goals, tasks, relevant tools of each stage of the brainstorming scheme.

Example. The figure below shows the number of visitors to the VKontakte social network in 2006 (by age). Collect data from official sites and build a similar schedule for 2019. Perform a comparative analysis of dynamic changes in a decade, draw causal conclusions.

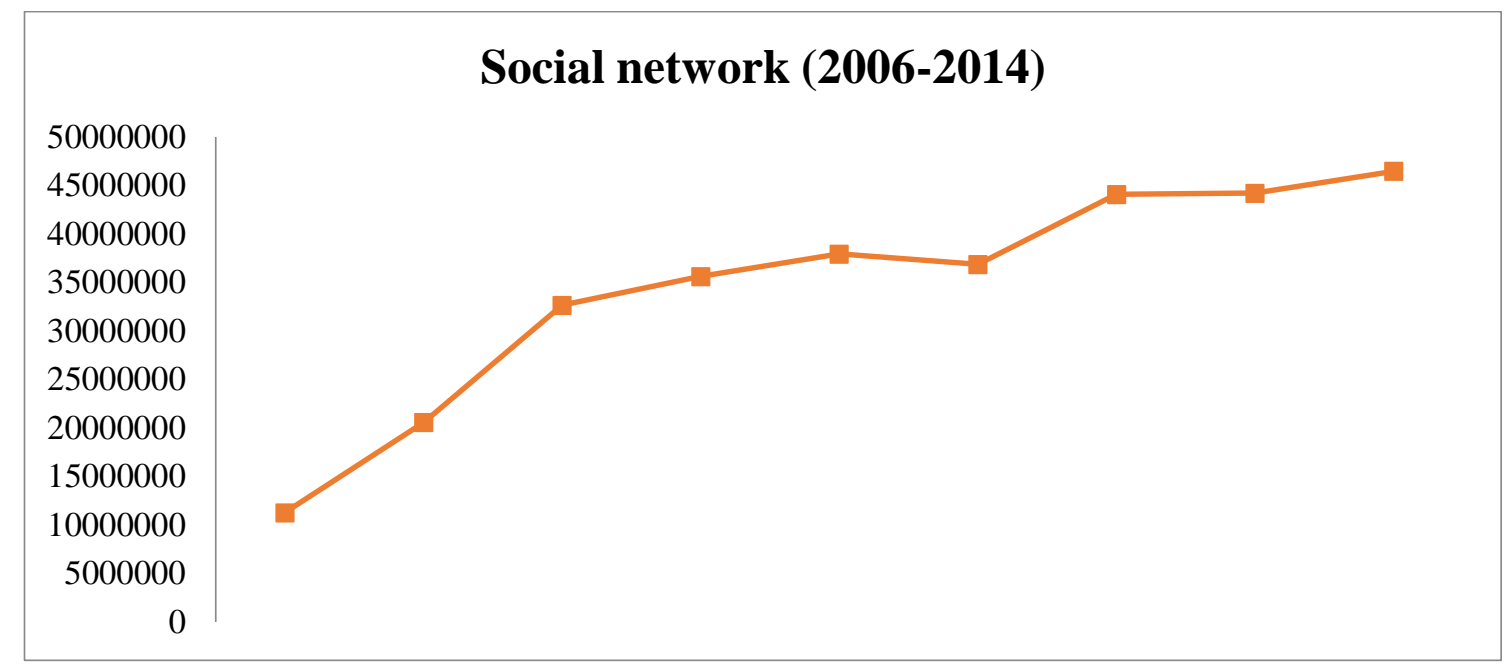

Example. The chart below shows the dynamics of computer crime. Conduct independent research, collect data on official sites (Kaspersky Lab, etc.) and plot individual types of crimes (for example, phishing, fraud, hacking, etc.). 


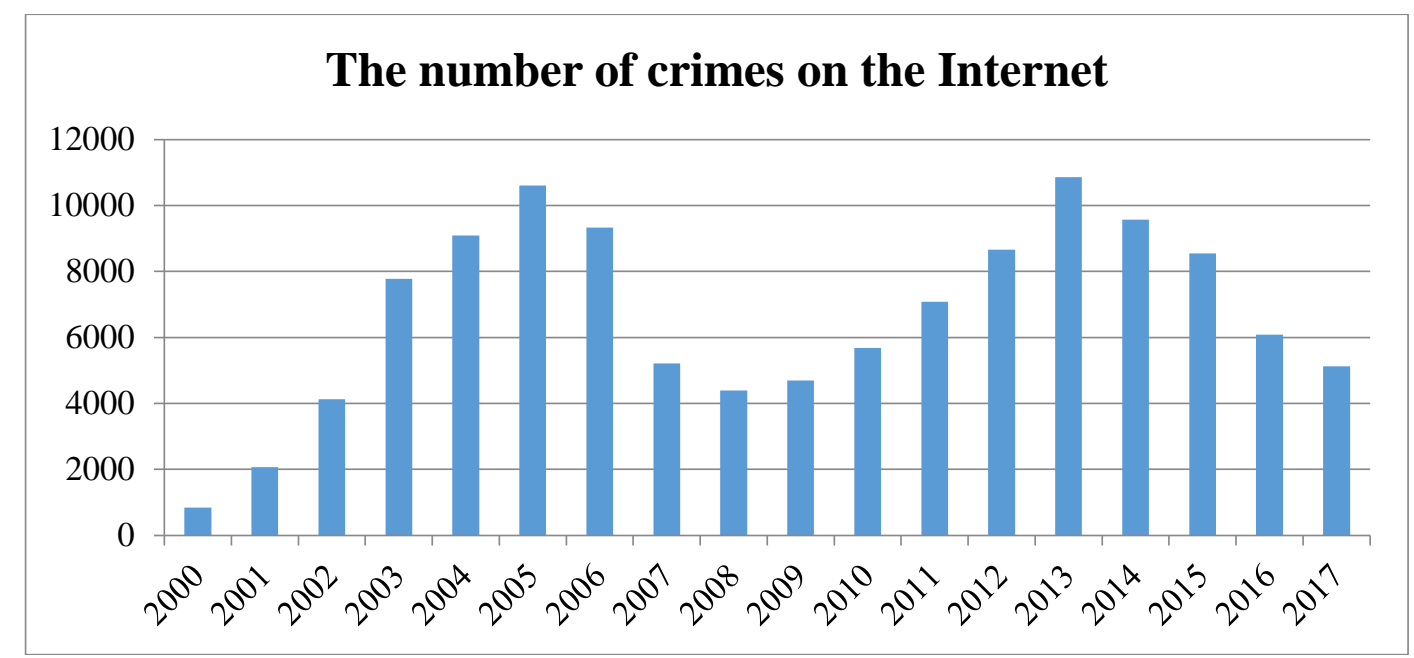

Example. Develop a web programming company security policy. The company has 5 departments (Designers, Programmers, Copywriters, Optimizers, and Project Managers) with 5 employees, Develop also the company's website usage policy (website user behavior policy).

\section{Conclusion}

Universities should experiment with parameters, both learning models and learner (profile) "scalable" adaptively. The infrastructure of the university should give each student a full opportunity to choose individual development cases in all subjects. He has to justify his choice, his situation, and his decision. The structure and approaches considered by us are aimed at the formation of a competent, cultural not only in the digital respect of the person. He must have his own, correct professional world view, market competitiveness.

The educational infrastructure "goes beyond" the university campus, is useful for large, with scientific developments, companies, and for staff development and retraining.

\section{References}

Berdnikova, L.F., Sherstobitova, A.A., Schnaider, O.V., Mikhalenok, N.O., Medvedeva, O.E. (2019). Smart university: assessment models for resources and economic potential. Smart Innovation, Systems and Technologies, 144, 583-593.

Efanova, T.I., Ivanov, A.B., Savitsky, S.K. et al. (2016). Information and educational environment of the university. New word in science: prospects for development. Works of the VII International Scientific and Practical Conference (Cheboksary, January 15, 2016). Chebaxars: Interactive plus, 1, 195-199.

Gluhova, L.V., Kaziev, V.M., Kazieva, B.V. (2018). System Rules of Financial Control and Management of Innovative Business Processes of the Enterprise. Journal of the Volga State University named after V.N. Tatischev, 2 (1), 118-121.

Gulevich, O.A. (2019). Psychology of mass communication: from newspapers to the Internet: textbook for universities. Moscow: Publishing house Jurite, 264.

Kaziev, V.M. (2012). Education and Internet. Values imaginary and true. Alma mater (Journal of Higher School), 2, 80-82.

Kaziev, K.V. (2011). E2E-situation analysis and decision making training with test tasks. Informatics and education, 8 (226), 31-36.

Kalimullina, A.M., Islamova, Z.I. (2016). Formation of Information-Educational Environment in the Partner Universities of University of Shanghai Cooperation Organization. IEJME - MATHEMATICS EDUCATION, 11 (6), 1879-1890.

Klug, J., Bruder, S., Kelava, A., Spiel, C., Schmitz, B. (2013). Diagnostic competence of teachers: A process model that accounts for diagnosing learning behavior tested by means of a case scenario. Teaching and Teacher Education, 30, 38-46. 
Korneeva, E., Voloshinova, M., Albaeva, A. (2019). Leading problems and prospects in the regulation of the digital economy. Proceedings of the 4-nd International Conference on Social, Economic end Academic Leadership (ICSEAL). doi: https://doi.org/10.2991/icsbal-19.2019.30.

Khenner, E., Stallmann, M. (2013). Preparation of IT-specialists: Russia and the US. Open systems, 3, 58-62.

Nazarov, D.M. (2018). Digital Economy as a Result of Information Revolutions. News of St. Petersburg State Economic University, 5 (113), 12-24.

Samir Abou El-Seoud M., Islam, A.T.F. Taj-Eddin, Naglaa Seddiek, Mahmoud M. El-Khouly, Ann Nosseir (2014). E-Learning and Student's Motivation: A Research Study on the Effect of E-Learning on Higher Education. iJET, 1.9 (4), 20-26. doi: http://dx.doi.org/10.3991/ijet.v9i4.3465.

Uskov, V.L., Bakken, J.P., Howlett, R.J., Jain, L.C. (2018). Smart Universities: Concepts, Systems, and Technologies, Springer, Cham., 421. doi: https://doi.org/10.1007/978-3-319-59454-5.

Vasilyeva, E.V., Pulyayeva, V.N., Yudina, V.A. (2018). Development of digital competences of civil servants of the Russian Federation. Business informatics, 4 (46), 28-42. doi: 10.17323/1998-0663.2018.4.28.42. 